\title{
Analysis of Port Community System Introduction in Croatian Seaports - Case Study Split
}

\section{Ivan Torlak ${ }^{a}$, Edvard Tijan ${ }^{b}$, Saša Aksentijevićc, Renato Oblak ${ }^{d}$}

The introduction of a Port Community System (PCS) is identified as one of the key elements facilitating seaport development. In this paper, the analysis of seaport stakeholders and Maritime Single Window systems in Croatia is performed, including NSW (National Single Window), MNSW (Maritime National Single Window: CIMIS - Croatian Integrated Maritime Information System), their interaction and development of the national model for a PCS, ongoing in the form of a pilot project in the Port of Rijeka. This development is selected as a precedent for creation of the nation-wide PCS to be used also in other cargo ports of national interest, including Split. Further building on this newly gained knowledge and taking into consideration the

\section{KEY WORDS}

$\sim$ Croatian searports

$\sim$ Split cargo port,

$\sim$ Seaport cluster

$\sim$ Port Community System development of the national PCS model, we explain the inherent characteristics of the Port of Split in terms of traffic evaluation in various port basins. We also provide a comprehensive set of operative guidelines for adjustment of the functional PCS module architecture to be deployed in the Port of Split and serving specific business needs of all identified port cluster's stakeholders after the initial development in the Port of Rijeka is completed.

\section{INTRODUCTION}

Six publicly open ports operate in the Republic of Croatia and have the status of 'port with special international economic interest' for the state. These are the Ports of Rijeka, Ploče, Zadar, Šibenik, Split, and Dubrovnik. Taking into consideration cargo operations using piers of port basins under the Port of Split Authority's management, the Port of Split can be characterised as one of the most complex port areas on the Croatian side of the Adriatic. The port itself offers various types of stevedoring and cargo handling services in its port basins. In order to improve the business processes and increase the level of quality of services offered by the port and port's stakeholders, it is of utmost importance to plan mid-term implementation of information technologies that strive to increase the quality of the provided services and enhance timely data exchange. Due to the use of information from different sources, the common problems are inconsistency and contradictions, which ultimately lead to inefficiencies of information systems in management support (Asproth, 2007).

The literature review shows that the trend towards collaborative innovation in the maritime supply chain implies a good understanding of the actors and their roles, and an efficient exchange of information (Carlan et al., 2016). Information systems 
have become indispensable to the competitiveness of ports, facilitating communication and decision making for enhancing the visibility, efficiency, reliability, and security in port operations under various conditions (Heilig and Voß, 2017). Strong facilitators of the digitalisation are investments into technology and cooperation for promoting information sharing and a better coordination and collaboration (Heilig et al., 2017).

Significant efforts have been done to enhance efficiency, effectiveness, and transparency of the port information flow by implementing different kinds of collaborative Port Information Systems, such as the Port Community Systems (PCSs). A PCS is an open electronic platform that enables information exchange among public and private port stakeholders, and its scope may cover a wide number of activities (Zerbino et al., 2019). PCS connects port community actors, enabling commercial services and information exchange between the port to their customers and a variety of stakeholders (Moros-Daza et al., 2020). It is very important to emphasize that a PCS must customize its services based on the type of users (Moros-Daza et al., 2018). PCSs are rapidly being developed in order to enhance the communications among ports and other port-related institutions and gain competitive advantage against the world's leading ports (Aydogdu and Aksoy, 2015). Analysing international solutions and good practice in the application of PCS, Constante (2019) provides valuable guidelines for cost-effective development of PCS.

Tsamboulas et al. (2012) assessed the changes in port performance resulting from the introduction of PCS, which directly affects the efficiency of port management in a competitive environment. Caldeirinha et al. (2020) analysed the various mechanisms that allow ports to adapt and develop PCS characteristics as well as new features that affect port performance.

The PCS helps port authorities to take the lead by providing a logistics solution to private actors, encouraging them to share information that may lead to lower logistics costs, to faster delivery/pickup in the import/export chain, and to higher customer satisfaction. Bringing all users together enhances the efficiency of the physical flow of freight, drives economic growth and, as a secondary result, assists in reducing externalities such as pollution, congestion, and land use impacts (Irannezhad, 2017).

Preliminary research (Tijan et al., 2014) has shown that the achieved level of development of PCS in Croatia is modest in terms of their use in the management of port facilities. The reasons identified for this issue are:

- The general issue of inadequate rate of ICT (information and communication technology) implementation in comparison with the speed of its overall development;

- Inadequate level of knowledge and adjustment ability of the entrepreneurs and the management caused by rapid scientific and technological development;

- Lack of knowledge and understanding of ICT as major economic resources;

- Inadequate level of employee education.

In addition, it has been noted that complex systems like the Croatian seaports are exposed to challenges of modern, dematerialised economy (Tijan et al., 2012).

Therefore, this paper will provide an overview of the development of a PCS in the Republic of Croatia so far (specifically, Ports of Ploče and Rijeka will be analysed, representing the bearers of the development of port information technologies, and the influence on the Port of Split). This paper will also analyse the involvement of the stakeholders of the seaport system and the transport chain. In order to achieve a satisfactory level of system usefulness in the Port of Split, the Split Port Authority should work closely with the Port Authorities of Rijeka and Ploče in order to derive benefits from their accumulated expertise in developing PCS Rijeka and Ploče that can help in the further development and implementation of a PCS in Split. Finally, this work will propose arrangement of macro-level modules for the processing and distribution of data, in a manner that will enable the system as a whole to function properly.

\section{PCS SPLIT AS PART OF CROATIAN NATIONAL SINGLE WINDOW}

As stated before, a PCS is an electronic platform that interconnects multiple information management systems operated by a variety of organizations and stakeholders that make up a port community cluster. A PCS is a platform that allows exchange between public and private operators in a port, by creating efficient processes, reducing procedure time and the use of paper documents (Vaghi and Lucietti, 2016). A PCS is also a digital solution for the optimization of port's commercial activities, and should represent an intermediary between all the users, CIMIS (Croatian Integrated Maritime Information System) and the Customs system of the Republic of Croatia, if it is given the role of a local Single Window under prescribed conditions and with appropriate authorisation and certificates for such purpose (Ministry of the Sea, Transport and Infrastructure, 2011).

The definition of a PCS determines the role of the system in port activities as support to all the commercial processes and activities within given process regulations. Its utilisation generally increases the use of electronic communication in the port cluster's businesses; the PCS's role is not management or administration by nature; in fact, it provides support to the commercial aspect of all stakeholders involved in seaport business. The final goal of the PCS implementation is an enhanced exchange of information, maintaining set standards of quality, reliability, and timeliness. Port-collaboration physical, information, and financial flows are 
interdependent, thus causing many coordination challenges for the parties in the port. As multiple organisations rely on a PCS, even for business-critical processes, effective governance of the collaboration is crucial (Chandra and van Hillegersberg, 2018).

Implementation of a PCS results in significant improvements to the time consumption of ship's arrival to the port that can be expected after process reengineering and especially after introduction of a PCS, which would result in increased efficiency and variable labour cost reduction (Tijan et al., 2014). For example, research has shown that only administrative labour savings related to ship processing can amount to $48.5 \%$ if proper reengineering is used and PCS is implemented (Tijan et al., 2014).

The National Single Window (NSW) can be defined as the standalone information system operating at national level, providing connectivity and data (document) exchange with other systems by using standard and well-established ways of communication, accepting information in strictly defined structure and making information available to various different stakeholders within the country in a harmonised manner (Mihai-Cosmin and Minea, 2016). Single Windows may also be supranational or regional. According to the Directive 2010/65/ EU of the European Parliament and of the Council (Directive 2010/65EU, 2010), each Member State should implement the Maritime National Single Window (MNSW) in order to optimise and facilitate the process of announcement and registration of ships that arrive to ports and/or depart from ports of the Member States (Tijan et al., 2017).

In order to achieve the cohesion goals during the implementation of the NSW, the European Commission has issued in mid-2019 a National Single Window Data Mapping Report, identifying full set of data to be exchanged using NSW among member states, aligned with the new requirements according to revised PAX legislation (European Commission, 2019).

PCS needs to be connected to the surrounding systems (such as CIMIS) with the underlying goal being avoidance of multiple data entry and facilitation of data exchange between stakeholders. Along with all the other systems enabling electronic communication in maritime traffic, PCS forms an important constituting and participating element of the NSW platform. The "Project of setting up a single national Port Community System" is currently underway, with the Ministry of the Sea, Transport and Infrastructure being the bearer of the project (Ministry of the Sea, Transport and Infrastructure, 2018). Cooperating parties in this project are, among others, the Port of Rijeka Authority and the Port of Ploče Authority. The latter maintains the only functional PCS system in the country used by the stakeholders in the port community, whose initial design started in 2009. (Buis, 2009) Since then, it has been constantly upgraded, so it presents a positive precedent for the development of a national PCS system to be implemented in other Croatian ports. Once the mentioned project is completed in 2021, all the Croatian Port Authorities will have a fully functional PCS system at their disposal, which will be adaptable to all Croatian cargo ports with very little changes and adaptation dependent on the local characteristics of each individual participating port. The Port of Split Authority, managing the second largest port in the Republic of Croatia (traffic of over 3.1 million tons of cargo), is currently not actively involved in the development of this project. This PCS system will follow all supranational guidelines set by the European Commission and UNECE, and especially those outlined by the European Port Community Systems Association. (European Port Community Systems Association, 2020). Furthermore, a set of guidelines presented by IPCSA (International Port Community Systems Association) will also be respected in the creation of a national PCS model. The IPCSA objectives are the following (International Port Community Systems Association, 2020):

- To ensure that the importance of Port Community Systems Operators is recognised internationally and in the EU and its member States, and that the sector is consulted substantively on any measure likely to affect it;

To ensure that the Port Community System Operators play their full part in delivering e-services internationally;

- To promote the highest possible standards in the European and International Port Community System Operators;

- To encourage all port communities to be proactive in the Port Community System development.

Stakeholders and users of PCS system can be divided into two groups (Tijan et al., 2017): stakeholders controlling the entered data, and commercial data users and providers.

Supervisory part of the application, i.e. agencies controlling the data entered are:

- Harbour Master's Office,

- Port Authority,

- Border police,

- Phytosanitary and veterinary inspections,

- Sanitary inspection, and

- Customs office.

Commercial users providing the data are:

- Waste disposal concessionaires,

- Mooring, piloting and tug service providers,

- Ships'agents,

- Freight forwarders,

- Cargo terminal concessionaires, and

- Land transport companies.

\subsection{PCS in Croatian Ports}

The Port of Ploče has made the most significant progress in the development and implementation of the PCS system. It is important to emphasise that the system developed in one port 
cannot be translated to another port in its entirety, but certain segments and basic logical settings of the system can.

The idea of the Port of Ploče was to make the port itself a hub where processes of trade and transport would be integrated. This project was designed under the title 'Project of Integration, Trade and Transport' (Port of Ploče Authority, 2018). The idea of this project was to transform the Port of Ploče from a traditionaltype port, an intersection of land and sea transport, into a modern logistical hub. This would create conditions to develop the Pan-European Corridor Vc (Poletan Jugović, 2006) whose route is Ploče - Osijek - Sarajevo, originating in the Port of Ploče.

The Port of Ploče PCS is in its mature development stage. It was intended to serve as a "local single window", and some of the basic implemented and supported processes are (Port of Ploče Authority, 2018):

- Integration of Notice of call with CIMIS,

- Integration with Terminal Operating System (TOS),

- Exchange of data based on XML (EXtensible Markup Language) and UN/EDIFACT (The United Nations rules for Electronic Data Interchange for Administration, Commerce and Transport),

- Customs procedures,

- $\quad$ Linking other forms of transport (road, rail),

- Procedures of cargo entry and exit, and

- Entry/exit and movement of cargo through the Port's Free zone.

Currently, the implementation of PCS module for the needs of operators of the liquid cargo terminal is underway in the Port of Ploče. In the Port area, the PCS system is used depending on the needs of the terminal operators and the concessionaires. Considering that the Port of Ploče Authority has built a new entry terminal, their goal is to automate the processes of this particular terminal. The PCS platform plays a key role in the process automation. Data is exchanged between different subsystems via defined business rules using the PCS platform. It is the priority to develop and integrate in the near future the module for the Notice for trucks' arrival. The intention is to connect the modules for permit issuing, Customs module, and module for port security. Finally, all terminal operators will be obligated to use a single system of notice, regardless of which Terminal Operating System (Tijan et al., 2010) they use.

Currently, the PCS is not implemented in the Port of Rijeka even though implementation was initially planned for 2008, and an international request for quotation was announced that received four valid offers and the selected vendor started with initial analysis and implementations. The project was suspended in 2011, partly due to the development of the CIMIS system and a change of focus. The effectuation of PCS continued in mid-2017 with preparations for the involvement of the project Technical Assistance (TA) whose the full implementation is planned by the end of 2021. The project is financed with the support of Connecting Europe Facility, in the amount of 1.6 million EUR. The Government of the Republic of Croatia will provide 15\% of that amount (Ministry of the Sea, Transport and Infrastructure, 2018). The project is well underway and executed on time. The contract for Technical Assistance for design and implementation of PCS in Rijeka, whose value is 297,312.50 Croatian kunas, was signed on 19 April 2018. The Technical Assistance team comprised of subject matter experts from Sarda Ltd., Aksentijevic Forensics and Consulting, Ltd., Faculty of Maritime Studies of the University of Rijeka, and Kiss Patterns immediately started with the activities whose goal is to produce the required PCS tender documentation including the involved Port stakeholders' process description, required hardware, system software and information security levels, rules for the transfer of intellectual property and business continuity. The public counselling process was announced on time on 24 December 2018. After the comments of interested public members were incorporated, the public procurement announcement was issued on 31 December 2018. Commercial offers were collected, requests for clarifications were issued, and the offers were technically and financially evaluated within rules set by the public procurement legislation rules according to which the Port of Rijeka Authority has to abide, with the final goal being the selection of an economically most viable offer for the implementation of PCS in Rijeka, which will serve as a basis for the nation-wide implementation of PCS after specific adjustments, including the Port of Split. The vendor was selected according to public procurement rules, and development and integration services contract was stipulated in April 2019. Within the portfolio of Connecting Europe Facility of the European Union instrument (Innovation and networks executive agency, 2016), this project carries the code "CEF-POR2CORE-PCS". (Port of Rijeka Authority, 2017)

The Port of Rijeka is situated on a Pan-European route called Corridor Vb (Croatian encyclopaedia, 2018). Its route is Rijeka Zagreb - Budapest. Apart from the corridor, the oil pipeline of great significance is connecting Rijeka to refineries in Croatia, Hungary, Serbia and Bosnia and Herzegovina.

Rijeka GATEWAY (Port of Rijeka Authority, 2018) project's goal is to develop and modernise the above-mentioned traffic route, i.e. to develop and modernise the Port of Rijeka as the point of intersection of maritime and land traffic. This project signifies a large breakthrough for Rijeka as a port hub. The following activities are planned as parts of the project: extricating piers from the city centre, modernising all the segments of operative port business, modernisation of the state road D 403, which will remove road traffic from the city centre (City of Rijeka, 2019), and implementing a modern PCS system. The particularity of the Port of Rijeka in comparison with the Port of Ploče is the dispersion of port basins and land terminals, which is limiting the development 
of the project since it requires additional human and financial resources to support diverse locations and modalities of cargo transport inside the Port itself. The development project should include all possible future users and stakeholders, and especially companies that operate within the seaport cluster. This applies most of all to the ports that have dislocated basins and different piers concessionaires. The current processes require multiplication of data, i.e. the same information needs to be entered several times delivered to multiple addresses, which increases the possibility of error and reduces the efficiency of the administrative and cargo-related procedures.

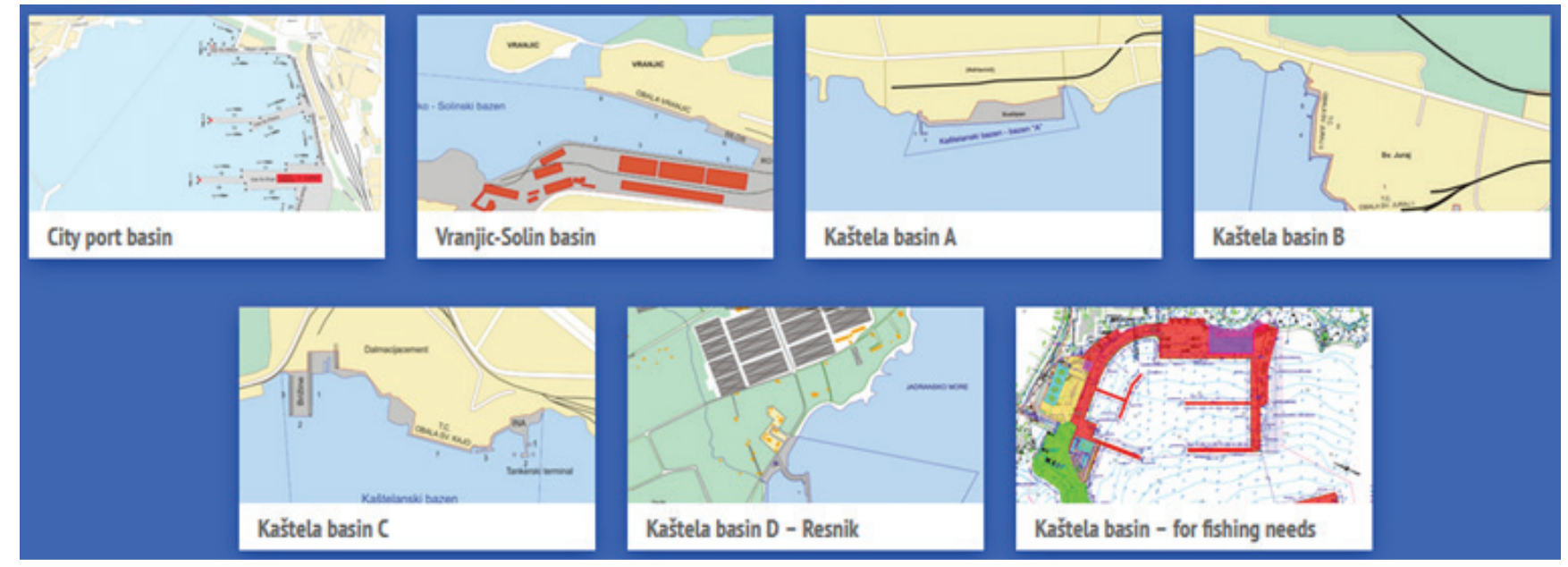

Figure 1.

Dock areas within competence of Port of Split Authority.

Source: Port of Split Authority, 2019

In 2017, using the cargo handling piers of the Split basin area, 3,136,347 tons of cargo were handled, which is a $14 \%$ increase in relation to the weight of goods handled in 2016. Most goods were handled in June, 357,566 tons (a 31\% increase in comparison with June 2016), and in July, 334,039 tons (a 55\% increase in comparison with July 2016) (Port of Split Authority, 2018).

The majority of cargo was handled at the piers for handling cement and cement products, $31.36 \%$ (983,535 tons), at the terminal for handling oil and oil derivatives - 13.88\% (435,170 tons), the North Port - $12.12 \%(380,125$ tons), and finally, at the silo-terminal for handling and storing grains - $6.62 \%(207,477$ tons). A large portion of cargo was transported by trucks to the islands or to Italy (967,330 tons) (Port of Split Authority, 2018).

Seven Port basins operate under the management of the Port of Split Authority, four of which are areas where cargo is handled. The Port basins where cargo is handled are Vranjic Solin basin, Kaštela basin B, Kaštela basin C, and City Port of Split. In the Port basin City Port of Split, truck traffic embarking on RO-

\subsection{Traffic Evaluation as Basis for Development of PCS in the Port of Split}

While the Port of Split is primarily considered as a passenger port, its function as a cargo port that has handled over 2.9 million tons of cargo in 2019 cannot be disregarded. According to the latest available data from year 2019, the Port of Split was the leading passenger port in the Republic of Croatia, with over 5.6 million passengers, and was the 3rd port in the tonnage of handled cargo (Port of Split Authority, 2020). The Port of Split operates in diverse and dislocated basins and several dock areas, as shown in the following Figure 1.

\section{.}


Ameropa žitni terminal Ltd. manages area known as Vranjic silo, which specialises in handling bulk grain - primarily corn, wheat and barley. In 2017, 207,477 tons of grains were handled, and a decrease of $34 \%$ in cargo manipulations was recorded in comparison with 2016. Vranjic silo (Ameropa žitni terminal Ltd.) handled $6.62 \%$ of all the cargo handled on piers under the management of the Port of Split Authority (Port of Split Authority, 2018) in 2017 and recorded 56 calls of cargo ships (Port of Split Authority, 2018).

\subsubsection{Kaštela Basin B}

Kaštela basin B is the area of the pier of Sv. Juraj (Eng. St. George Pier) - CEMEX Hrvatska Llc cement factory, concessionaire of the Port area. The area is used for the needs of the cement factory: cement, clinker, ground granulated blast furnace slag (GGBFS), petrol coke and thermal coal cargo manipulations. In the year 2017, 983,535 tons were handled, 310 calls of cargo ships were recorded, and an increase of $31 \%$ was achieved in comparison to 2016 (Port of Split Authority, 2018). The Pier of St. Juraj factory handled $31 \%$ of all the cargo handled under the management of the Port of Split Authority (Port of Split Authority, 2018).

\subsubsection{Kaštela Basin C}

Kaštela basin $C$ incorporates several piers, of which the most important are:

- INA - tanker terminal, and

- St. Kajo - CEMEX Hrvatska LIc, cement factory.

The national integrated oil company INA Inc. of Zagreb is the concessionaire of INA - tanker terminal area. The terminal is used for the coastal shipping of fuel, which is usually loaded in the Port of Bakar and unloaded at this terminal. In 2017, 435,170 tons were handled, and an increase of $23 \%$ was achieved in comparison with 2016. INA - tanker terminal handled $13.88 \%$ of all the cargo traffic (Port of Split Authority, 2017) and achieved 127 commercial ship calls (Port of Split Authority, 2018).
St. Kajo - CEMEX Hrvatska LIc is a concessionaire of the Port area and uses the piers for manipulation of ground granulated blast furnace slag (GGBFS) and cement. In 2017, 211,260 tons were handled and an increase of $15 \%$ was achieved in comparison with 2016 (Port of Split Authority, 2018). St. Kajo CEMEX Hrvatska Llc recorded 48 commercial ship calls (Port of Split Authority, 2018).

\section{PROPOSAL OF FUNCTIONAL PCS MODULE ARCHITECTURE IN THE PORT OF SPLIT}

Plans for the development of the Port of Split, unlike the above-mentioned Ports of Ploče and Rijeka, do not contain implementation and execution of a PCS project of such magnitude for the entire Port cluster. However, according to the plans of the Ministry in charge, the future system implemented in the Ports of Ploče and Rijeka will have inherent ability to function also in other Croatian Ports, after installation and adjustment of the system to the needs of each particular Port. The important part of preparation for implementation is adapting the business processes and achieving compliance with the legislative framework. The introduction of ICT business process support (such as PCS) can be counterproductive if the state agencies in charge do not fully endorse implementation of e-commerce principles and standards. The implementation and subsequent utilisation of CIMIS system indicates the possibility of such a problem because certain state bodies still require both electronic and paper documentation, with the paper documentation being mandatory.

As mentioned above, the Port of Split will have the option of PCS implementation after the Ports of Ploče and Rijeka. The systems comprised of modules are either already implemented or are in the process of implementation in those Ports. Each Port's system should have the same basic modules, while additional modules would differ depending on the specific needs of an individual Port. The proposed modules belong to the class of business application software that also includes information router service and certificate server used for user authentication. General composition of PCS modules is shown in Figure 2.
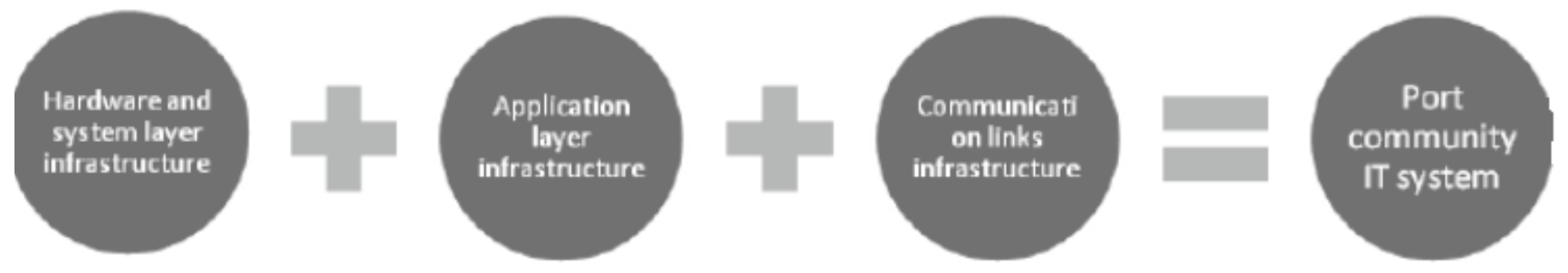

Figure 2.

General composition of PCS module.

Source: Tijan et al., 2009. 
The authors propose the following modules for initial implementation in the Port of Split PCS:

- Port administration module,

- Module for notices of arrival,

- Module for ISPS (International Ship and Port Facility Security Code) control of Port areas,

- Modules for bulk, liquid, and general cargo, and

- Interconnection module connecting TOS of the container terminal and PCS.

The implementation of these modules will enable all the three macro-functions of PCS, which are data and documentation storage (recording), information processing, and information management (Naglić et al., 2015).

All the business processes facilitated by the PCS should be fully aligned with the needs of the members of the Port cluster, with the objective of reengineering and digitalization of the business processes currently conducted using traditional methods (paperwork and physical document flow, and management). They should also be in line with the legal and EU regulations and requirements, and the respect of good business practices of the seaport cluster.

\subsection{Port Administration Module and Module for Notices of Movement of Ships and Cargoes}

Several processes can be grouped under the umbrella of 'notice of arrival of ships', all of which serve the purpose of fulfilling administrative procedural requirements for the preparation of ships and cargo for the execution of Port operations. The processes governing the arrival of ships in the Port of Split are outdated in comparison to the contemporary processes used by modern Ports, and have not been changed for over four decades in the cargo management part, except for the introduction of CIMIS system, related to ship formalities, which will be integrated with the PCS system.

Currently, CIMIS system performs the role of a single national interface for the registration of arrivals and departures of ships, and management of the mandated formalities. Among other functions, its role as the collector of data should be used in the future setup of the Port's PCS. (Puškarić, 2013). Below are listed those processes that are currently executed in dual manner through CIMIS system and by physical delivery of the paper documents. Such processes slow down business execution in the seaport cluster.

The procedure of registering the arrival of ship to the Customs office in charge is carried out dually. Via CIMIS system, the Customs office is provided by the shipping agent with data and information such as:

- IMO (International Maritime Organization) crew list,

- IMO crew effect declaration,

- Cargo manifest and stowage plan,
- IMO ship store declaration,

- IMO narcotic and nil list,

- ISPS list of last ten Ports visited, and

- Declaration of dangerous and polluting goods (only if applicable).

The Customs office still requires paper (i.e. physical) version of the documents listed above in the so-called Cargo statement, and the operators'TOS systems are not used for this purpose. This results in the slowdown of the operative work of those in charge for cargo management and creates avoidable delays.

The arrival of cargo is registered by using the 'Customs e-expediter' application. This application, with CIMIS system, constitutes the national system of registering the movement of ships and cargo. Currently, these two systems have no interconnectivity. The same as CIMIS, 'Customs e-expediter' should have the role of a data collector for the future PCS in the Port of Split. It has a dual role while registering ships:

- Security registration of cargo done by the ship's agent: Customs office uses this process to assign the MRN (Movement Reference Number) numbers. When the agent acquires the requested MRN numbers and the permission to enter the cargo into the Republic of Croatia's territory, the ship's agent is obligated to deliver the above-mentioned data to the Customs office.

- Summary cargo declaration is a document used by the cargo agent to report to the Customs that the cargo is stored in the Customs' warehouse. After the Customs release this document to the agents, they need to present it again to the Customs office before each further action with the cargo.

During its stay in the Port and under the Customs' supervision, every movement of the cargo through the Port needs to be reported by physically handing in a document called 'Cargo disposition'. This document is made using the Port of Split TOS. The authors suggest connecting the TOS application to the future PCS to avoid the multiplication of paperwork.

All the mentioned processes can be simplified by increasing the level of interconnectivity of the already existing information technology solutions used by seaport cluster's stakeholders. The PCS's administrative module, CIMIS, and the Customs e-expediter can help the cluster's stakeholders to simplify their own administrative procedures and facilitate mutual communication.

\subsection{Module for ISPS Control of Port Areas}

A basic prerequisite for any business, especially for businesses closely related to international traffic, is a high level of security regarding the flow of cargo and persons. International Ship and Port Facility Security (ISPS) Code (IMO, 2019) states the minimal conditions prescribed by the International Maritime Organization (IMO) via SOLAS (IMO, 2019) convention that Ports open for international traffic have to fulfil. In its essence, 
it is a system of controls of movement through the Port areas. As defined by the IMO, ISPS code is a comprehensive set of measures used to enhance the security of ships and Port facilities, developed in response to the threat to ships and Port facilities in wake of 9/11 attack in the United States (Steenbergen et al., 2013).

As seaports are places where land and sea traffic meet, control of the entrances and exits to and from the Port area is necessary. Due to its dispersion, there is no uniform system of movement control in the Port of Split. The authors suggest that the Port of Split's PCS establishes a module that will satisfy the conditions of the ISPS system regarding tracking of the movement of persons, goods, and vehicles in Port areas. It is necessary to enable the entry of the notice or arrival via the ISPS module of the PCS. The authorized users that would conduct those entries could easily and efficiently ensure the passage for persons and vehicles into the Port area. This could achieve a multitude of positive effects with the primary one being an increased level of security.

Possible commercial benefits for the Port itself are various. As every private and legal entity doing business in the Port area must pay concession fees, this would eliminate those commercial activities that are not subject to fees. This system would be most beneficial to the area under the management of Luka Inc. (the North Port). Since the highest level of vehicle traffic is found precisely at the entrance to the area of this Port basin, a higher degree of control and charging entry to persons and vehicles could be achieved. The Customs could precisely follow the movement of cargo and vehicles if the system is to be linked to truck scales. This would also simplify the processes of delivering cargo dispositions and controlling cargo movements. Perhaps the most important effect could be achieved in the peak moments of the traffic at the Port's entrance if the entrance itself is to be 'ICT-enabled'. If the entrance is to be able to recognise the vehicles announced via the PCS, unnecessary delays at the Port's gates could be avoided. This would result in shorter waiting times, which in turn usually means financial savings.

In the medium term, an important role of the ISPS module will also be the management of data gathered from the Internet of Things (IOT) and similar platforms used in the logistics processes in the Port. The convergence of various technologies will raise numerous questions, and maritime cargo logistics sector will certainly not be left out of the development. These questions can be divided into several categories that need to be addressed, among them the most important being information security, design, sustainability and environmental impact and privacy, autonomy and control (Aksentijević et al., 2015). Considering the rapid adoption of this technology, its position can be naturally recognized and situated within the ISPS module. From the recent developments, it is evident that traceability of this information will be crucial for security purposes, and it is quite possible that storage will be achieved using blockchain or similar general ledger technology (Tijan et al., 2019).

\subsection{Module for Bulk, Liquid and General Cargo}

The most important module of the proposed Port of Split's PCS is the 'Module for bulk and general cargo'. Its importance is visible in two functions: the first is the Port's primary function of cargo manipulation and storage. The second function is specific to the Port of Split, whose primary type of cargo is bulk cargo, which is handled by the majority of the Port cluster's stakeholders. The bearers of the development of this module should be the largest concessionaires, Luka Inc., CEMEX Hrvatska Llc cement factory, Ameropa Žitni terminal Ltd., and INA tanker terminal. The Port of Split's advantage over e.g. the Port of Ploče is the fact that the TOS is used only by one concessionaire, i.e. Luka Inc., and is not used for handling bulk cargo, but only for container traffic management.

The processes included in this module should be connected to other processes in the modules pertaining to administrative processes of the movement of ships and cargo. Connecting data in such a way can accomplish the basic purpose of the PCS system, i.e. process optimisation and the reduction of multiple data entry. The data entered through this module would be available to other modules since the underlying logic of the system is to distribute information through the whole system.

The basic purpose of this module is to track entry, internal movement, and exit of all the cargo covered by this module. The documents used in these processes in the Ports in the Republic of Croatia are diverse and sometimes depend on the Port-specific practices of each Customs office. They include various tracking documents and dispositions that follow cargo movement and storage, and all the data on the Customs' records. The PCS facilitates these processes since a large number of these documents currently need to be handed in physically to the Customs offices, a procedure which complicates and slows down the work of cargo agents and shippers.

Since the PCS is a process-based system, it should entail all the procedures in cargo traffic, a fact that is especially reflected in this module where the emphasis is on the cargo management and all the processes necessary for the Port cluster's business.

\subsection{Connecting TOS to PCS Module}

The Port of Split TOS system was developed solely by the concessionaire Luka Inc., and it is exclusively used as a support for container traffic. The system serves only a small number of the processes necessary for recording actions involving cargo containers. The TOS records the processes through which the Port communicates with its own system, and these are: 
- Cargo storing request,

- Order for loading and unloading of cargo into containers,

- Container status reports, and

- Booking of containers.

According to Gekara, et. al., (2020), "Ports, and particularly container terminals, are the central nodes in these complex supply chains, so much so that their individual performance determines the performance of entire global supply chains. They are therefore under increasing innovative pressure to maintain optimum performance in terms of productivity and efficiency. Consequently, the past four decades, beginning in the mid-1980s, have seen a proliferation of ICT products specifically designed for the optimisation of container port administration, management and operations. These systems are generally known as Container Terminal Operating Systems or CTOS in abbreviation."

Cargo and ship agents have access to these processes, but they do not have the ability to enter information into the system, which slows down the business processes. Delivery orders, notices of cargo's arrival into Port and cargo manifest cannot be exchanged with the Port via TOS. Instead, they are sent using e-mail or fax. The Customs office does not use the data available in the system, but instead, requests the Port and the agents to deliver the data as paper documents.

Once the implementation of the PCS into Port of Split is well underway and achieves high level of adoption, it will be necessary to connect TOS and the PCS to achieve the complete exchange of information. In order to avoid synchronisation, if commercial stakeholders decide so, it would be fully feasible for them to stop using TOS for cargo-container handling and use TOS functionalities within the PCS itself. Such a solution will be possible when the PCS attains high level of development. In addition, this scenario needs to be mutually agreed with the managing body of the Port of Split, i.e. the Port of Split Authority.

\section{CONCLUSION}

The PCS implementation should be viewed as the continuation of digitalisation of seaport cluster operations in the Republic of Croatia. The current level of e-commerce adoption is not satisfactory, and that it is one of the reasons why Croatian seaports are less competitive than other competing Adriatic seaports. The bearer of the PCS development endeavour is the Ministry of the Sea, Transport and Infrastructure, also in charge of all the seaports of the state interest, among which are the Ports of Split, Rijeka, and Ploče. The introduction of CIMIS was supposed to have been the first step towards the development of a single window for maritime business in the Republic of Croatia. Without the legislative changes that would obligate all the stakeholders of the seaport cluster (especially government bodies) to accept new methods of processing data within the Port businesses, the implementation of the PCS will not entirely fulfil the expectations of the involved stakeholders. As the PCS is a service aimed at seaport cluster stakeholders, the architecture of the system, implemented processes, and all other segments necessary for the creation of such a complex system should not be defined before a high-quality analysis of the needs of the cluster's stakeholders is conducted. By using this approach, it is possible to upgrade the logic within the procedures and achieve an adequate level of optimisation that would certainly decrease expenses in the later phases of implementation and increase the level of satisfaction and efficiency of all the stakeholders involved. The PCS alone cannot be a generator of the development of seaports, i.e. a high level of system implementation will not increase the handled tonnage in the Croatian seaports regardless of its quality, but will surely be an important segment in the development of seaports and their preparation for a faster business growth.

Taking into consideration that the tentative instance of PCS in the Port of Split will be the third PCS system in the Croatian Ports, the process of implementation will be simpler in Split than in Rijeka and Ploče. Each Port's system should have the same basic modules; additional modules must cater to specific needs of each individual Port. Each process that is facilitated in the PCS should be fully aligned with the needs of the members of Split seaport cluster and with the objective of increasing the level of business optimisation.

\section{ACKNOWLEDGEMENT}

This paper has been financially supported by the University of Rijeka under the Faculty of Maritime Studies' projects.

\section{REFERENCES}

Aksentijević, S., Krnjak, D., Tijan, E., 2015. Logistics environment awareness system prototype based on modular Internet of Things platform, Scientific Journal of Maritime Research, 29 (1), pp. 170-179. Available at: https://hrcak.srce.hr/149934.

Asproth, V., 2007. Integrated Information Systems - A Challenge for Long-Term Digital Preservation. Interdisciplinary Journal of Information, Knowledge, and Management, 2, pp.089-098. Available at: http://dx.doi.org/10.28945/102.

Aydogdu, Y.V. \& Aksoy, S., 2015. A study on quantitative benefits of port community systems. Maritime Policy \& Management, 42(1), pp.1-10. Available at: http://dx.doi.org/10.1080/03088839.2013.825053.

Buis, J., 2009. Port Community System for the Port of Ploče, Amsterdam Port Consultants, September 2009., Internal project documentation presentation.

Caldeirinha, V. et al., 2020. The impact of port community systems (PCS) characteristics on performance. Research in Transportation Economics, 80, p.100818. Available at:

http://dx.doi.org/10.1016/j.retrec.2020.100818.

Carlan, V., Sys, C. \& Vanelslander, T., 2016. How port community systems can contribute to port competitiveness: Developing a cost-benefit framework. Research in Transportation Business \& Management, 19, pp.51-64. Available at: http://dx.doi.org/10.1016/j.rtbm.2016.03.009. 
Chandra, D. R., \& van Hillegersberg, J., 2018. Governance of inter-organizational systems: a longitudinal case study of Rotterdam's Port Community System, International Journal of Information Systems and Project Management, 6 (2), pp. 4768. Available at: https://www.sciencesphere.org/ijispm/archive/ijispm-060203.pdf.

City of Rijeka, 2019. Project for the construction of the state road D403 from the Škurinje junction to the port of Rijeka. Available at: https://www.rijeka.hr/pocetkomiduce-godine-pocetak-radova-na-izgradnji-drzavne-ceste-dc-403/, accessed on 10 May 2019.

Constante, J.M., 2019. International case studies and good practices for implementing Port Community Systems, Inter-American Development Bank. Available at: https:// publications.iadb.org/publications/english/document/International_Case_ Studies_and_Good_Practices_for_Implementing_Port_Community_Systems.pdf, accessed on 29 September 2020.

Croatian encyclopedia, 2020. List of land transport corridors. Available at: http:// www.enciklopedija.hr/natuknica.aspx?ID=46418, accessed on 11 June 2020.

European Commission, 2019. Directive 2010/65/EU on Reporting Formalities, National Single Window Data Mapping Report, Version: 1.9 final, 19 June 2019. Available at: https://ec.europa.eu/transport/sites/transport/files/nsw-datamapping-report.pdf, accessed on: 11 October 2020.

European Port Community Systems Association, 2020. How to develop a Port Community System. Available at https://www.unece.org/fileadmin/DAM/trade/ Trade_Facilitation_Forum/BkgrdDocs/HowToDevelopPortCommunitySystemEPCSAGuide.pdf, accessed on 10 October 2020

Gekara, V.O. \& Nguyen, X.-V.T., 2020. Challenges of Implementing Container Terminal Operating System: The Case of the Port of Mombasa from the Belt and Road Initiative (BRI) Perspective. Journal of International Logistics and Trade, 18(1), pp.49-60. Available at:

http://dx.doi.org/10.24006/jilt.2020.18.1.049.

Heilig, L., Lalla-Ruiz, E. \& Voß, S., 2017. Digital transformation in maritime ports: analysis and a game theoretic framework. NETNOMICS: Economic Research and Electronic Networking, 18(2-3), pp.227-254. Available at: http://dx.doi.org/10.1007/s11066-017-9122-x.

Heilig, L. \& Voß, S., 2016. Information systems in seaports: a categorization and overview. Information Technology and Management, 18(3), pp.179-201. Available at: http://dx.doi.org/10.1007/s10799-016-0269-1.

Innovation and networks executive agency, 2016. Upgrade of the Rijeka Port infrastructure - Port Community System (POR2CORE-PCS) - 2016-HR-TMC-0082-S. Available at: https://ec.europa.eu/inea/en/connecting-europe-facility/ceftransport/2016-hr-tmc-0082-s, accessed on: 6 October 2020

International Maritime Organization, 1974. International Convention for the Safety of Life at Sea SOLAS, 1974. Available at: http://www.imo.org/en/About/ Conventions/ListOfConventions/Pages/International-Convention-for-the-Safetyof-Life-at-Sea-(SOLAS)-1974.aspx, accessed on 15 May 2020

International Maritime Organization, 2020. ISPS Code. Available at: http://www.imo. org/en/OurWork/Security/Guide_to_Maritime_Security/Pages/FAQ.aspx, accessed on: 15 May 2020

International Port Community Systems Association, 2020. Mission \& Objectives. Available at: https://ipcsa.international/about/mission, accessed on: 9 October 2020 .

Irannezhad, E., Hickman, M. \& Prato, C.G., 2017. Modeling the Efficiency of a Port Community System as an Agent-based Process. Procedia Computer Science, 109, pp.917-922. Available at:

http://dx.doi.org/10.1016/j.procs.2017.05.422.
Niculescu, M.-C. \& Minea, M., 2016. Developing a Single Window Integrated Platform for Multimodal Transport Management and Logistics. Transportation Research Procedia, 14, pp.1453-1462. Available at:

http://dx.doi.org/10.1016/j.trpro.2016.05.219.

Ministry of the Sea, Transport and Infrastructure, 2011. Prerequisites for building an integrated IT infrastructure of MMPI system with the goal of achieving functionality NSW, Zagreb. Available at: https://mmpi.gov.hr/UserDocsImages/arhiva/NSW\%20 Studija\%2012_11.pdf, accessed on: 3 May 2020.

Ministry of the Sea, Transport and Infrastructure, 2018a. Conference of Digitalisation in Maritime Traffic, Zagreb. Available at: http://mppi.hr/default.aspx?id=10393, accessed 3 May 2020.

Ministry of the Sea, Transport and Infrastructure, 2018b. Improvement of the infrastructure of the port of Rijeka - information system of the port community. Available at: http://www.mppi.hr/default.aspx?id=34136, accessed on: 12 July 2020.

Moros-Daza, A., Amaya-Mier, R. \& Paternina-Arboleda, C., 2020. Port Community Systems: A structured literature review. Transportation Research Part A: Policy and Practice, 133, pp.27-46. Available at: http://dx.doi.org/10.1016/j.tra.2019.12.021.

Moros-Daza, A. et al., 2018. A multivariate analysis for the creation of Port Community System approaches. Transportation Research Procedia, 30, pp.127-136. Available at: http://dx.doi.org/10.1016/j.trpro.2018.09.015.

Naglić, M., Tijan, E., Aksentijević, S., 2015. Container terminal business information systems, ICT Security Conference Proceedings, Slović, S. (ed.), Kladovo, Serbia, 14. 16. May, College of Economics and Administration, pp. 95-114. Available at: https:// www.scribd.com/doc/298163707/Zbornik-Radova-IKT-Bezbednost-2015-ICTSecurity-Kladovo-Republika-Srbija, accessed 3 May 2020.

Poletan Jugović, T., 2006. The Integration of The Republic of Croatia Into The Paneuropean Transport Corridor Network, Scientific Journal Of Maritime Research, 20(1), pp. 49-65. Available at: https://hrcak.srce.hr/4006.

Port of Ploče Authority, 2020a. Integration, Trade and Transport (ITT) Project. Available at: https://www.ppa.hr/hr/projekt-itt/, accessed on: 23 May 2020.

Port of Ploče Authority, 2020b. PCS information system. Available at: https://www. ppa.hr/hr/lucki-informacijski-sustav/, accessed on: 3 August 2020.

Port of Rijeka Authority, 2017. CEF - POR2CORE - PCS. Available at: https://www. portauthority.hr/en/european-projects/cef-por2core-pcs/, accessed on: 5 October 2020.

Port of Rijeka Authority, 2019. Rijeka Gateway Project. Available at: http://www. portauthority.hr/en/development_projects/rijeka_gateway_project, accessed on 1 May 2019.

Port of Split Authority, 2017a. Annual cargo traffic report for 2017. Available at: https://portsplit.hr/, accessed on: 10 October 2019.

Port of Split Authority, 2017b. Cargo traffic report for 1991 - 2017 period. Available at: https://portsplit.hr/, accessed on: 18 October 2019

Port of Split Authority, 2019. Dock areas within the competence of Port Authority Split. Available at: https://portsplit.hr/, accessed on 4 March 2019.

Port of Split Authority, Harbor operations center, 2017. Report for 2017, Available at: https://portsplit.hr/, accessed on: 30 October 2019.

Puškarić, J., Martinčić-Ipšić, S. \& Tijan, E., 2013. Data Warehouse Development in Maritime Traffic. Journal of Maritime \& Transportation Science, 49-50(1), pp.167179. Available at:

http://dx.doi.org/10.18048/2015.49-50.167. 
Steenbergen, R.D.J.M. et al. eds., 2013. Safety, Reliability and Risk Analysis. Available at: http://dx.doi.org/10.1201/b15938.

Tijan, E., Agatić, A., \& Hlača, B., 2010. ICT evolution in container terminals, Scientific Journal of Maritime Research, 24(1), pp. 27-40. Available at: https://hrcak.srce. $\mathrm{hr} / 54924$.

Tijan, E., Aksentijević, S., Čišić, D., 2014. Seaport cluster information systems - a foundation for Port Community Systems' architecture, MIPRO 2014, 37th International Convention Proceedings, Opatija 2014, pp. 1774-1779. Available at: http://dx.doi.org/10.1109/MIPRO.2014.6859813.

Tijan, E., Aksentijević, S., Hlača, B., 2012. Investment Analysis of Information Security Management in Croatian Seaports, MIPRO 2012, 35th International Convention Proceedings, Rijeka 2012, pp. 1783-1788. Available at: https://www.researchgate. net/publication/261424870_Investment_analysis_of_Information_Security_ Management_in_Croatian_seaports.

Tijan, E., Aksentijević, S., Hlača, B., 2014a. Seaport cluster labour cost reduction - a modelling approach, Scientific Journal of Maritime Research, 28 (2), pp. 103-110. Available at: https://hrcak.srce.hr/131698.

Tijan, E., Aksentijević, S., Hlača, B., 2014b. Simulation of administrative labour costs in seaport clusters, Scientific Journal of Maritime Research, 28(1), pp. 22-30. Available at: https://hrcak.srce.hr/123239.

Tijan, E. et al., 2019. Blockchain Technology Implementation in Logistics. Sustainability, 11(4), p.1185. Available at: http://dx.doi.org/10.3390/su11041185.
Tijan, E., et al., 2017. Elaborate development of the single interface for formalities in maritime traffic (NSW), University of Rijeka, Faculty of Maritime Studies, Rijeka, Croatia. Available at: https://mmpi.gov.hr/UserDocs/mages/arhiva/Elaborat\%20 razvoja\%20jedinstvenog\%20pomorskog\%20sucelja_PFRI\%202017\%2022-1_18. pdf, accessed on: 28 July 2019.

Tijan, E. et al., 2018. Integrating Maritime National Single Window with Port Community System - Case Study Croatia. Digital Transformation - Meeting the challenges. Available at:

http://dx.doi.org/10.18690/978-961-286-170-4.1.

Tijan, E., Kos, S., Ogrizović, D., 2009. Disaster Recovery and Business Continuity in Port Community Systems, Scientific Journal of Maritime Research, 23(1), pp. 243260. Available at: https://hrcak.srce.hr/38367.

Tsamboulas, D., Moraiti, P. \& Lekka, A.M., 2012. Performance Evaluation for Implementation of Port Community System. Transportation Research Record: Journal of the Transportation Research Board, 2273(1), pp.29-37. Available at: http://dx.doi.org/10.3141/2273-04.

Vaghi, C. \& Lucietti, L., 2016. Costs and Benefits of Speeding up Reporting Formalities in Maritime Transport. Transportation Research Procedia, 14, pp.213-222. Available at: http://dx.doi.org/10.1016/j.trpro.2016.05.057.

Zerbino, P. et al., 2019. Towards Analytics-Enabled Efficiency Improvements in Maritime Transportation: A Case Study in a Mediterranean Port. Sustainability, 11(16), p.4473. Available at:

http://dx.doi.org/10.3390/su11164473. 